\title{
Research and Analysis Report on School-running Characteristics of Local Higher Educational Institutes in Jilin Province under the Strategic Background of "Establishing Jilin into a Higher Education-oriented Province" Strategy
}

\author{
Chunyan $\mathrm{Wu}^{1, \mathrm{a}}$,Yanhua $\mathrm{Yu}^{1, \mathrm{a}}$,Dongming Zhang ${ }^{1, \mathrm{a}}$, Chenjun Shen ${ }^{1, \mathrm{a}}$ \\ 1 Academic Affair Office, Jilin Agricultural University, Changchun, Jilin, 130118 \\ a183904267@qq.com
}

\begin{abstract}
Keywords: Establishing Jilin Province into a Higher Education-oriented Province Strategy; Local Higher Educational Institutes; School-running characteristics
\end{abstract}

\begin{abstract}
The provincial government of Jilin Province puts forth the "establishing Jilin Province into a higher education-oriented province" strategy, including to change the development mode of higher education with it centring on promoting the quality development of higher education industry. A distinctive school-running method is the key to the self development of higher educational institutes and the accomplishment of "establishing Jilin Province into a higher education-oriented province" strategy. Based on the research and analysis on the school-running characteristics of 37 higher educational institutes in Jilin Province, this paper will conclude their achievement in developing their own school-running characteristics, analyze problems existing in their characteristic school-running process. By doing so, this research aspires to seek a scientific way for developing universities' school-running characteristics so that they cans serve the economic and social development in local area, and to provide reference for universities in terms of their school-running positioning, perfecting their school-running function and making policies and establishing systems etc.
\end{abstract}

\section{Introduction}

The school-running characteristics of a university refer to a sustainable and stable way of development and a widely recognized, unique and scientific way of operating within a college or university during its process of development [1]. While developing the school-running characteristics of university, such factors as a university's comparative advantages in disciplines, research, teaching and social service shall be taken into consideration [2-3].

In order to understand how universities and colleges in Jilin Province adapt to and implement the work of developing their own school-running characteristics outlined in the strategy of "establishing Jilin Province into a higher education-oriented province", the author studied the official websites of 37 colleges and universities in Jilin Province. From the websites, the author collected and processed the evaluation reports relating to undergraduate teaching work of all 37 universities and colleges, self evaluation reports and undergraduate teaching quality reports of some universities etc. in recent years etc. From those reports, the author gathered the information about the running characteristics of those universities, conducted interviews with the education managers of 11 universities and colleges and analyzed the history of their school-running characteristics and the facts based on which such characteristics were established. Through the analysis on those primary data, the author aspires to conclude the achievement of higher education institutes in Jilin in terms of their schoolrunning characteristics and some problems existing in the process, intending to provide some strategic support for the successful accomplishment of higher education-oriented strategies. After material analysis, field interview, and data analysis, this paper comes to the following conclusions: 


\section{The school-running characteristics of provincial level universities and their achievements in developing their school-running characteristics.}

Those universities have become more aware of establishing their own school-running characteristics and proposed there own development strtegies for school-running characteristics.

In accordance to the author's research on some official documents and websites of 37 colleges and universities in Jilin Province, and in view of the analysis on their quality reports, the author found out that in the increasingly intensive environment for developing higher education, especially after Evaluation Scheme of Teaching Quality of General Higher Education Institutes confirms special programs of university as an important evaluation indicator, all higher educational institutes within Jilin Province have developed their strategies for promoting school-running characteristics correspondingly.

For instance, Jilin Agriculture University proposed the strategy of "facing the problems of farmers, rural areas and agriculture and establishing discipline and discipline cluster in a scientific manner; setting up the system in which faculty-level board of directors is held responsible for open school running; establishing a mechanism combining teaching, research and social service, and putting knowledge into practice”. Jilin Agriculture University considers school operation as an integral part of its overall development strategy, and it takes active part in incorporating its distinctive school operation method into various aspects including its disciplines majors and talent cultivation method etc.

\section{The integration of distinctive school-running characteristics and disciplines with advantages.}

When analyzing the official documents and websites of higher educational institutes in Jilin Province, all the colleges and universities emphasize the fact that during the process of establishing their own school-running characteristics, they pay great attention to base on their traditional operation advantages, benefit from the traditional disciplinary advantages to form their unique discipline characteristics.

Changchun University of Chinese Medicine puts forward the strategy of centring on Chinese traditional medicine, combining teaching with research and production, and taking initiative in making contribution to local economic and social development. While Changchun Institute of Technology puts forward the goal of "establishing itself into an educational institute with distinctive disciplines and majors, a university which serves the local area and makes great contribution to the well-being grass groups.”

\section{The establishment of school-running characteristics of provincial level universities and the combination of geographic advantage.}

According to the research, as local universities, provincial-level colleges and universities can depend on the local area to serve the economic and cultural development of local area and provide the local area with talents and qualified employees during the process of developing distinctive school running. However, those colleges and universities are required to combine its disciplines, majors, and development with the local economic and industrial structure. In addition, while trying to promote the economic and social development of local area, they should also make full use of their unique resources, geographic characteristics and other regional advantages to establish an unique charm. During the process of talent cultivation and discipline construction, those 37 colleges and universities in Jilin Province have fully realised the importance of pooling local resources for self-development and developing their own school-running characteristics. "Serving the local area" has been outline in the development goals of 9 colleges and universities. (See Table 1) 
Table 1 Popular words frequently occurred in 37 universities and colleges in Jilin

\begin{tabular}{|l|l|l|l|l|l|}
\hline Popul & Innovation & Practice & $\begin{array}{l}\text { Combining teaching } \\
\text { with research and } \\
\text { production }\end{array}$ & $\begin{array}{l}\text { Serving } \\
\text { Local } \\
\text { Area }\end{array}$ & Application \\
\hline Frequency of occurrence & 5 & 10 & 6 & 9 & 6 \\
\hline
\end{tabular}

\section{Problems existing in the process of developing one's distinctive school-running characteristics}

A university's running positioning not only involves the positioning of operation types and majors, it also requires the positioning in how to cultivate talents with distinctive characteristics and advantages. So far, in terms of school-running characteristics, most colleges and universities are similar in their talent training mode. For most higher education institutes, their talent training modes do not feature a quality standard that can distinguish themselves from their competitors. Through researching on the development trend of Chinese universities since 1949, the author also found out that the lost of characteristics in talent cultivation is the result of adjusting to institutional environment, which is a common scene among Chinese universities and colleges.

Specialties and majors can best reflect a university's school-running characteristics. This is particularly true for universities and colleges in Jilin Province, as most of them are teachingresearching intensive or teaching intensive universities. Universities in its essence is a place in which different majors are formed into groups in line with their features, so the running characteristics of universities are mostly reflected in their specialties designs.

Through the research and analysis on the specialities design of 37 universities and colleges in Jilin, the author has found out that there is a trend for convergence in specialties in those universities. those majors that can be found in more than $50 \%$ of all colleges and universities (19) in Jilin are listed. It can be seen that English major can be found in $94.6 \%$ universities, the figure for Marketing major is $89.2 \%$ and over $70 \%$ for Visual Communication Design major and Environment Design which are two majors traditionally considered as less popular art-related majors. Through the above mentioned figures, it can be seen that most universities and colleges are blindly following others while designing their majors and specialties. There even exist some higher educational institutes which introduced some popular majors without considering their teaching conditions, lack of qualified teachers and their own school-running characteristics. What's even worse, those universities even lay emphasis on popular majors to attract students, which leads to such severe problems as short of teachers, poor experiment and practice environment for students etc. in the process of talent training.

\section{Lack of effort in developing their own school-running characteristics}

Through interviews, the author found out that for those long established universities, their school-running characteristics are developed along with their long history, and thus are recognized by students and staff and attested in practice. While for some newly established colleges and universities, especially those independent ones, their school-running characteristics are formed through the following process: the idea is firstly discussed within the university, and then submitted to the management level, for example, the Academic Board for approval. Therefore, without seeking a widespread recognition from teachers and students, nor spending a long period of time to develop the concept, some universities and colleges will declare the establishment of their schoolrunning characteristics. Under such circumstances, it is unavoidable that some of their measures 
will be too general and even impracticable. Even if some of the measures are practicable, those universities will fail to implement them in an accurate manner. Therefore, even after years of development, those universities will still lack their own school-running characteristics that are widely accepted by their students and teaching faculties. The major reason leading to such problem is that those universities didn't lay much emphasis on developing their school-running characteristics. In addition, due to such factors as short history or lack continuity in implementation, it is difficult for them to develop a distinctive school-running mode that are recognized by its own communities and by the society at large. Based on this analysis, it is suggested that those universities are required to invest more efforts in developing and insist in implementing their school-running characteristics.

In accordance to the above-mentioned analysis, it can be found out that even though higher educational institutes in Jilin have made some achievements in developing their own characteristics in terms of school running, there still exist some insufficiencies. Therefore, universities and colleges in Jilin are required to seize the strategic opportunity of "establishing Jilin into a higher educationoriented province", strive for development and develop themselves into universities with obvious advantages and distinctive characteristics through continuous efforts.

\section{Acknowledgement}

Research and Practice on Curriculum Optimisation in Local Agriculture Universities under the Context of Higher Education Reform, project relating to The Twelfth Five Year Planning Project for Education Science in Jilin Province (No. ZD15053)

\section{Reference}

[1]Chen Q H, Li H Y, Chen W. Characteristics of Applied University Education [J]. Chinese Vocational and Technical Education, 2016, 04:33-37.

[2]Jiang T. The vitality of the development of Local Normal Universities: the characteristics of running a school [J]. Journal of Heilongjiang College of Education, 2016, 01:1-3. 